О. О. Дядик ${ }^{3}$ Ю. І. Бекетова ${ }^{1}$ Н. М. Горбоконь ${ }^{2}$ М. Д. Іванова ${ }^{1}$

\title{
Патоморфологічні особливості IgG4-пов'язаної склерозуючої хвороби шлунка: клінічний випадок
}

\author{
${ }^{1}$ Національний медичний університет імені О. О. Богомольця, м. Київ, Україна, \\ ${ }^{2}$ Діагностично-консультаційний центр CSD Health Care, м. Київ, Україна,
}

${ }^{3}$ Національна медична академія післядипломної освіти імені П. Л. Шупика, м. Київ, Україна

Ключові слова: хвороба шлунка, патологічні зміни, імуноглобулін С, кишкові хвороби.

\begin{abstract}
3 моменту першого згадування в середині 90-х років минулого століття в науковій літературі неухильно зростає чисельність даних про хворобу, що асоційована з IgG4. При цьому розширюється перелік органів і тканин, серед котрих переважають підшлункова залоза, слинні залози та лімфатичні вузли. Дотепер висвітлено 6 випадків ураження органів шлунково-кишкового тракту, два з них спостерігались у шлунку з мінімальним акцентом на патогістологічних змінах і клінічних проявах, а також по одному у стравоході, порожній кишці, сліпій і сигмоподібній кишках.

Серед пацієнтів $3 \mathrm{IgG} 4$-асоційованою патологією переважають чоловіки середнього та старшого віку. Єдиним симптомом найчастіше $\epsilon$ наявність пухлиноподібного утворення в одному або кількох органах без ознак запалення, макроскопічно без гіперемії та проявів системності уражень. Спільними лабораторними показниками є підвищення сироваткового глобуліну, IgG, IgG4, підвидів IgE та низький титр аутоантитіл - таких як ревматоїдний та антинуклеарний фактори. Патоморфологічні ознаки варіюють залежно від органа, який уражається. Виділено діагностичні морфологічні критерії при екстранодулярній локалізації патологічних процесів: лімфоплазмоцитарна інфільтрація з тенденцією до формування фолікулів, склероз без клітинної міофібробластичної проліферації, флебіт, значний тканинний $\operatorname{IgG4}{ }^{+}$плазмоцитоз без ураження стінок артерій (окрім випадків, що описані в легенях та аорті). Під час встановлення діагнозу IgG4-пов'язаної/зумовленої патології беруться до уваги критерії, запропоновані Cheuk та Chan: > 50 IgG4 плазматичних клітин при великому збільшенні та співвідношення $\operatorname{IgG4} 4^{+} / \mathrm{IgG}^{+}>40 \%$. Підрахунок базується на оцінюванні трьох полів зору з найбільшою інтенсивністю забарвлення, що корелює 3 ділянкою площею 0,196 мм².

У контексті сучасних відомостей про IgG4-пов'язану/зумовлену патологію різних органів представляємо власне спостереження IgG4-пов'язаної/зумовленої склерозуючої хвороби шлунка у 29-річного чоловіка. Наведені дані клінічних, лабораторних і патоморфологічних досліджень, обгрунтований діагноз.
\end{abstract}

Патологія. - 2016. - №3 (38). - С. $97-101$

\section{Патоморфологические особенности IgG4-сопряжённой склерозирующей болезни желудка: клинический случай}

\section{Е. А. Дядык, Ю. И. Бекетова, Н. Н. Горбоконь, М. Д. Иванова}

С момента первого упоминания в середине 90 -х годов прошлого века в научной литературе неуклонно растёт численность данных о болезни, ассоциированной с IgG4. В процесс вовлекается всё больше органов и тканей, среди которых преобладают поджелудочная железа, слюнные железы и лимфатические узлы. До сих пор освещены 6 случаев поражения органов желудочно-кишечного тракта, два из которых наблюдались в желудке с минимальным акцентом на патогистологических изменениях и клинических проявлениях, а также по одному в пищеводе, тощей кишке, слепой и сигмовидной кишке.

Среди пациентов с IgG4-ассоциированной патологией преобладают мужчины среднего и старшего возраста. Чаще всего единственным симптомом является наличие опухолевидного образования в одном или нескольких органах без признаков воспаления, макроскопически без гиперемии и проявлений системности поражений. Общими лабораторными показателями являются повышение сывороточного глобулина, IgG, IgG4, подвидов IgE и низкий титр аутоантител - таких как ревматоидный и антинуклеарный факторы. Морфологические признаки варьируют в зависимости от органа, который поражается. Выделены диагностические морфологические критерии при экстранодулярной локализации патологических процессов: лимфоплазмоцитарная инфильтрация с тенденцией к формированию фолликулов, склероз без клеточной миофибробластической пролиферации, флебит, значительный тканевой $\mathrm{IgG4} 4^{+}$плазмоцитоз без поражения стенок артерий (кроме случаев, описанных в лёгких и аорте). При установке диагноза IgG4-связанной/обусловленной патологии учитываются критерии, предложенные Cheuk и Chan: $>50$ IgG4 плазматических клеток при большом увеличении и соотношение IgG4 $/ \operatorname{IgG}^{+}>40 \%$. Подсчёт базируется на оценке трёх полей зрения с наибольшей интенсивностью окраски, коррелирует с участком площадью 0,196 мм².

В контексте современных сведений об IgG4-связанной/обусловленной патологии различных органов представлено собственное наблюдение IgG4-связанной/обусловленной склерозирующей болезни желудка у 29-летнего мужчины. Приведены данные клинических, лабораторных и патоморфологических исследований, обоснован диагноз.

Ключевые слова: желудка болезни, патологические изменения, иммуноглобулин $C$, кимечные болезни.

Патология. - 2016. - 3 (38). - С. 97-101

Pathomorphological features of IgG4-releated sclerosing disease of the stomach: case report

O. O. Dyadyk, Yu. I. Beketova, N. M. Gorbokon, M. D. Ivanova

Since the first description in the middle of the 1990's of last century, it has been steadily increasing the number of literary data concerning IgG4-related disease. The process involved more organs and tissues with predominance of pancreas, salivary glands, and 
lymph nodes affection. There are several documented cases arising in the gastrointestinal tract. The salient clinical features include a predisposition to affect middle-age men who present with the only symptoms referable to a mass lesion at one or more sites, without inflammation, hyperemia and other constitutional symptoms. Common laboratory features are elevated serum globulin, IgG, IgG4, and IgE subtypes and low titers of autoantibodies such as rheumatoid factor and ANA. Histological features vary depending on the affected organ. But there are some common features of extranodal sites: lymphoplasmacytic infiltration with lymphoid follicle formation, sclerosis, phlebitis, and significant tissue IgG4 ${ }^{+}$-plasmocytosis. The arteries usually are not involved in the inflammatory process. The most common features in the lymph nodes are follicular hyperplasia, interfollicular expansion and Castelman-like appearance. There are proposed by Cheuk and Chan criteria for the diagnosis such as $>50$ IgG4 plasma cells per HPF and IgG4 $+/ \operatorname{IgG}+>40 \%$ ratio. The calculation is based on the assessment of the 3 fields of view with the greatest color intensity and correlates with the area of $0.196 \mathrm{~mm}^{2}$.

The pancreas, salivary glands, hepatobiliary tract, orbit and lymph nodes are cites most frequently, although other sites such as the aorta, skin, central nervous system, breast, kidney, prostate, lung, and thyroid have also been occasionally reported. There are 6 cases reports of involving the GIT, 2 of them were described in the stomach, one case in esophagus, jejune, cecum and sigmoid colon. Most cases took the form of a circumscribed nodule, variably affecting the mucosa, submucosa, muscularis propria, and subserosa. Microscopically it was formed by paucicellular hyalinized fibrous tissue with patchy chronic inflammatory infiltrate compound with plasma cells and lymphocytes. The proposed by Cheuk and Chan criteria were present in 4 of these cases. In the case with involving the jejune there were diagnosed serum IgG4 elevation at $800 \mathrm{mg} / \mathrm{dL}$, phlebitis and necrotizing mesenteric arteritis. IgG4 ${ }^{+}$plasma cells also were seen within the interfollicular region of mesenteric lymph nodes.

In this report, we present the case of IgG4-related disease involving stomach, omentum and mesenteric lymph nodes. A previously well 29-year-old man presented with a 1-year history of intermittent epigastric pain, nausea and sometimes vomiting. Because of worsening and suspicion of cancer resection of stomach was made. Morphological investigation of stomach tissue revealed a chronic ulcer associated with transmural inflammatory infiltrate rich in IgG4-positiv plasma sells. Abundant IgG4+ interfollicular plasma cell were also identified in a lymph node in stomach serosa, lymph nodes of omentum and mesenteric lymph node. In view of sensitivity to steroids, this condition should be considered in the differential diagnosis of stomach ulcers and gastritis with severe plasma cell infiltration, especially in case of negative $\mathrm{H}$. Pylori and absence of response to ordinary anti-inflammatory treatment.

Our observation of IgG4-releated sclerosing disease of the stomach in 29-year-old male was carried out in context of modern information about IgG4-releated pathology of different organs. Data of clinical, laboratory, and pathomorphological studies which help to substantiate the diagnosis were presented.

Key words: Stomach Disease, Patologic Processes, Immunoglobulin C, Intestinal Diseases.

Pathologia 2016; №3 (38): 97-101

3, моменту першого згадування в середині 90-х років минулого століття [1] у науковій літературі неухильно зростає кількість даних про хворобу, що асоційована 3 IgG4. При цьому розширюється перелік органів і тканин, які можуть бути уражені при цій патології, найчастіше до патологічного процесу залучаються підшлункова залоза, слинні залози та лімфатичні вузли [2]. Серед літературних посилань $є$ поодинокі згадки і про ураження органів шлунково-кишкового тракту.

Відомо, що серед пацієнтів з IgG4-асоційованою патологією достеменно переважають чоловіки середнього та старшого віку. Сдиним симптомом зазвичай постає наявність пухлиноподібного утворення в одному або кількох органах без ознак запалення, макроскопічно без гіперемії та проявів системності уражень [3]. Спільними лабораторними показниками є підвищення сироваткового глобуліну, $\operatorname{IgG}, \operatorname{IgG} 4$, підвидів $\operatorname{IgE}$ та низький титр аутоантитіл - таких як ревматоїдний та антинуклеарний фактори. Патоморфологічні ознаки варіюють залежно від органа, який уражається. Виділено діагностичні морфологічні критерії при екстранодулярній локалізації патологічних процесів: лімфоплазмоцитарна інфільтрація $з$ тенденцією до формування фолікулів, склероз без клітинної міофібробластичної проліферації, флебіт, значний тканинний $\mathrm{IgG4}{ }^{+}$плазмоцитоз. Слід відзначити, що стінки артерій до таких уражень не залучаються, окрім випадків, що описані у легенях [4,5] та аорті [6-11]. Так, у спостереженнях JR. Stone зі співавт. [11,12] IgG4-зумовлене пошкодження аорти становило 75 \% усіх випадків так званих лімфоплазмоцитарних аортитів. Що ж до лімфатичних вузлів, то описані фолікулярна гіперплазія та перифолікулярна експансія, але найхарактернішою $є$ поява реактивних лімфатичних фолікулів, в яких можуть розташовуватись гіалінізовані судинні структури, та перифолікулярна інфільтрація лімфоцитами, плазматичними клітинами (як при хворобі Кастельмана) [13].

Під час встановлення діагнозу IgG4-пов'язаної/зумовленої патології беруться до уваги критерії, що запропоновані W. Cheuk i JK. Chan [3]: > 50 IgG4 плазматичних клітин при великому збільшені та співвідношення IgG4 ${ }^{+}$ $\mathrm{IgG}^{+}>40 \%$. Підрахунок базується на оцінюванні трьох полів зору з найбільшою інтенсивністю забарвлення, що корелює 3 ділянкою площею 0,196 мм².

Отже, на сьогодні це захворювання впевнено діагностується в підшлунковій залозі, але зростає кількість повідомлень про можливе залучення різних органів, що схиляє до думки про системність уражень. Підшлункова залоза, слинні залози, гепатобіліарна система, орбіта та лімфатичні вузли є найуразливішими. 3'являються поодинокі повідомлення з описом вказаних вище змін в аорті, шкірі, центральній нервовій системі, молочних залозах, нирках, простаті, легенях і щитоподібній залозі [2].

Дотепер висвітлено 6 випадків ураження органів шлунково-кишкового тракту, два 3 них спостерігали у шлунку з мінімальним акцентом на патогістологічних змінах і клінічних проявах, а також по одному у стравоході, порожній кишці, сліпій і сигмоподібній кишках $[14,15]$. В усіх цих спостереженнях визначались чітко відмежовані вузли, котрі варіабельно локалізувались у товщі слизового, підслизового, м'язового та субсероз- 
ного шарів. Вузли побудовані із гіалінізованої сполучної тканини з морфологічними проявами хронічного запального інфільтрату, в якому переважали плазматичні клітини та лімфоцити. У чотирьох із цих випадків визначали описані раніше критерії, що запропоновані Cheuk та Chan. При ураженні порожньої кишки встановлене підвищення рівня сироваткового IgG4 до 800 мг/дл, а також діагностовано флебіт у прилеглій брижі та некротичний артеріїт мезентеріальних судин (хоча некрози не є ознакою, що притаманна цій патологіi). $\operatorname{IgG} 4^{+}$плазматичні клітини визначались також у перифолікулярних зонах мезентеріальних лімфатичних вузлів [14].

Ми презентуємо клінічний випадок IgG4-пов'язаної/ зумовленої склерозуючої хвороби з ураженням шлунка. Молодий чоловік, 29 років, протягом 12 місяців скаржився на періодичний біль різної інтенсивності в епігастральній ділянці та нудоту, що не пов'язані з прийманням їжі; зрідка блювотиння. В анамнезі - хронічний бронхіт. Щодо інших органів і систем, особливих скарг не було. Обстеження на віруси гепатиту В і C показало негативні результати. Загальний аналіз крові - без патологічних змін, швидкість зсідання еритроцитів i C-реактивний білок - у межах норми. Під час рентгенологічного дослідження грудної та черевної порожнин ніяких специфічних змін не виявили. Ультразвукове дослідження підшлункової залози, печінки, селезінки, нирок і наднирників патології не верифікувало.

Під час фіброгастроскопії документовано потовщення складок і ригідність слизової оболонки з наявністю виразки на малій кривині в антральному відділі. При біопсії шлунка встановлений діагноз хронічного гастриту iз загостренням. Повторне ендоскопічне дослідження 3 біопсією, котре здійснили через 2 місяці після лікування, показало такі самі зміни. Через підозру на рак проведена резекція шлунка. Під час операції виявили множинні лімфовузли брижі тонкої кишки, один з них узятий для патогістологічного аналізу.

Здійснивши макроскопічне дослідження операційного матеріалу, виявили фрагмент шлунка (розмірами 7 см по малій кривині та 9 см - по великій) із сальником. На розрізі на малій кривині визначалась виразка 3 х 1 см зі щільними валикоподібними краями та дном сіруватого кольору. Над виразкою серозна оболонка була помірно потовщеною та щільною. На суміжних ділянках складки слизової оболонки збільшені, дещо ригідні. Стінка шлунка на розрізі нерівномірно потовщена (до 1,5 см на сусідніх до виразки ділянках), однак їі шари диференціювались. У сальнику визначалися множинні лімфовузли еластичної консистенції, сіро-рожевого кольору, розмірами від 0,5 до 1,5 см. Окремо на патогістологічне дослідження був надісланий лімфовузол (1,5 х 0,8 х 0,5 см) такої самої будови.
Проаналізувавши патоморфологічні мікропрепарати, що забарвлені гематоксиліном та еозином, підтвердилась наявність хронічної виразки, котра проникала в підслизовий шар, з ознаками склерозування у дні та регенерацією слизової оболонки по краях. На прилеглих ділянках спостерігали потовщення складок унаслідок гіперплазії покривно-ямкового епітелію, кістозне розширення ямок, гіперсекреція слизу та вогнищева тонкокишкова метаплазія. Привертала увагу виражена дифузна запальна інфільтрація слизової та підслизової оболонок плазмоцитами $з$ домішкою лімфоцитів, макрофагів, нечисленних еозинофілів і поодиноких нейтрофільних лейкоцитів. Переважання в запальному інфільтраті плазмоцитарних клітин особливо помітне під час використання імуногістохімічного забарвлення на CD138, при цьому плазмоцити були негативні стосовно маркера CD56, що виключало їхню пухлинну природу. Інфільтрація поширювалась по міжм'язових сполучнотканинних прошарках до серозної оболонки.

Підслизовий шар був значно потовщений зі склерозом та осередками ліпоматозу, містив лімфоїдні фолікули з гермінативними центрами. У локусах, що віддалені від виразки, значних патологічних змін не спостерігали. На одній із ділянок у серозній оболонці виявлений лімфовузол з ознаками фолікулярної гіперплазії, гістіоцитозу синусів, плазмоцитарною інфільтрацією міжфолікулярної тканини. Такі самі зміни наявні в окремо надісланому лімфовузлі брижі та лімфовузлах сальника.

Імуногістохімічне дослідження тканин шлунка показало, що майже 50 \% плазмоцитів - позитивні на IgG4. Кількість клітин на одне поле зору в середньому дорівнювало 57 (підрахунок здійснювали у трьох полях зору великого збільшення). У лімфатичних вузлах кількість IgG4-позитивних плазмоцитів становила приблизно 40 \% із переважним розташуванням їх в інтерфолікулярній зоні.

Отже, сукупність патоморфологічних ознак і результати імуногістохімічного дослідження дали можливість встановити діагноз IgG4-пов'язаної/зумовленої склерозуючої хвороби шлунка. Відзначимо, що пацієнт був виписаний зі стаціонара в задовільному стані через 10 діб після операції. Цей випадок унаочнює прояви IgG4-пов' язаної/зумовленої склерозуючої хвороби шлунка з залученням у процес лімфовузлів сальника та брижі тонкої кишки. Враховуючи чутливість до лікування стероїдами, захворювання повинно включатися до диференційної діагностики виразок і гастритів із вираженою плазмоцитарною інфільтрацією стінки, особливо при негативній реакції на пілоричний хелікобактер, а також відсутності позитивної динаміки на традиційну протизапальну терапію. Підвищення рівня сироваткового IgG4 може слугувати додатковою (але надзвичайно важливою) диференційно-діагностичною ознакою.

Конфлікт інтересів: відсутній.

\section{Список літератури}

1. Chronic pancreatitis caused by anautoimmune abnormality. Proposal of the concept of autoimmune pancreatitis / K. Yoshida, F. Toki, T. Takeuchi et al. // Dig Dis Sci. - 1995.
- №40. - P. 1561-1568.

2. Prevalence and distribution of extrapancreatic lesions complicating autoimmune pancreatitis / H. Hamano, N. Arskura, T. Muraki et al. // Journal Gastroenterology. - 2006. - №41. - P. 1197-1205. 
3. Cheuk W. IgG4-related sclerosing disease a critical appraisal of an evolving clinicopathologic entity / W. Cheuk, J.K. Chan // Adv Anat Pathol. - 2010. - №17. - P. 303-332.

4. Distinctive pulmonary histopathology with increased IgG4positive plasma cells in patients with autoimmune pancreatitis: report of 6 and 12 cases with similar histopathology / B. Shrestha, H. Sekiguchi, T.V. Colby et al // Am J Surg Pathol. - 2009. -№33. - P. 1450-1462.

5. IgG4-related lung and pleural disease: a clinicopathologic study of 21 cases / Y. Zen, D. Inoue, A. Kitao et al // Am J Surg Pathol. - 2009. - №33. - P. 1886-1893.

6. IgG4-related inflammatory abdominal aneurysm of the aortic arch / M. Ishida, M. Hotta, R. Kushima et al. // Pathol Int. 2009. - №59. - P. 269-273.

7. IgG4-related inflammatory abdominal aortic aneurysm associated with autoimmune pancreatitis / H. Ito, Y. Kaizaki, Y. Noda et al. // Pathol Int. - 2008. - №58. - P. 421-426.

8. A case of multiple immunoglobulin G4-related periarteritis: a timorous lesion of the coronary artery and abdominal aortic aneurysm / Y. Matsumoto, S. Kasashima, A. Kawashima et al. // Hum Pathol. - 2008. - №39. - P. 975-980.

9. Qian Q. Ruptured abdominal aortic aneurysm related to IgG4 periaortitis / Q. Qian, K.B. Kashani, D.V. Miller // N Engl J Med. - 2009. - №361. - P. 1121-1123.

10. IgG4-positive plasma cells in inflammatory myofibroblastic tumor: inflammatory abdominal aortic aneurysm: the possibility of an aortic manifestation of $\mathrm{IgG} 4$-related sclerosing disease / N. Sakata, T. Tashiro, N. Uesugi, et al // Am J Surg Pathol. - 2008. - №32. - P. 553-559.

11. IgG4-related systemic disease accounts for a significant proportion of thoracic lymphoplasmacytic aortitis cases / J.R. Stone, A. Khosroshahi, V. Deshpande, et al. // Arthritis Care Res(Hoboken). - 2010. - №62. - P. 316-322.

12. Stone JR. Aortitis, periaortitis, and retroperitoneal fibrosis, as manifestations of IgG4-related systemic disease / J.R. Stone // CurrOpin Rheumatol. - 2011. - №23. -P. 88-94.

13. Lymphadenopathy of IgG4-related sclerosing disease / W. Cheuk, H.K. Yuen, S.Y. Chu, et al. // Am J Surg Pathol. 2008. - №32. - P. 671-681.

14. Wong D. IgG4-related sclerosing disease of the small bowel presenting as necrotizing mesenteric arteritis and a solitary jejuna ulcer / D. Wong, S. Pillai, M. Kumarasinghe // Am J Surg Pathol. - 2012. - №36. - P. 929-934.

15. Sclerosing nodular lesions of the gastrointestinal tract containing large numbers of IgG4 plasma cells / R. Chetty, S. Serra, G. Gauchotte, et al. // Adv Anat Pathol. - 2010. №17. - P. 303-332.

\section{References}

1. Yoshida, K., Toki, T., Takeuchi, T., Shin-Ichiro W., Keiko S., \& Naoaki H. (1995). Chronic pancreatitis caused by anautoimmune abnormality. Proposal of the concept of autoimmune pancreatitis. Dig Dis Sci., 40, 1561-1568. doi: 10.1007/ BF02285209.

2. Hamano, H., Arskura, N., Muraki, T., Ozaki, Y., Kiyosawa, K., \& Kawa, S. (2006). Prevalence and distribution of extrapancreatic lesions complicating autoimmune pancreatitis.
Journal Gastroenterology, 41, 1197-1205. doi: 10.1007/ s00535-006-1908-9.

3. Cheuk, W., \& Chan, J. K. (2010). IgG4-related sclerosing disease a critical appraisal of an evolving clinicopathologic entity. Adv Anat Pathol., 17, 303-332. doi: 10.1097/ PAP.0b013e3181ee63ce.

4. Shrestha, B., Sekiguchi, H., Colby, T. V., Graziano, P., Aubry, M. C., Smyrk, T. C., et al. (2009). Distinctive pulmonary histopathology with increased IgG4-positive plasma cells in patients with autoimmune pancreatitis: report of 6 and 12 cases with similar histopathology. Am J Surg Pathol., 33, 1450-1462. doi: 10.1097/PAS.0b013e3181ac43b6.

5. Zen, Y., Inoue, D., Kitao, A., Onodera, M., Abo, H., Miyayama, S., et al. (2009). IgG4-related lung and pleural disease: a clinicopathologic study of 21 cases. Am J Surg Pathol., 33, 1886-1893. doi: 10.1097/PAS.0b013e3181bd535b.

6. Ishida, M., Hotta, M., Kushima, R., Asai, T., \& Okabe, H. (2009). IgG4-related inflammatory abdominal aneurysm of the aortic arch. Pathol Int., 59, 269-273. doi: 10.1111/j.14401827.2009.02363.x.

7. Ito, H., Kaizaki, Y., Noda, Y., Fujii S., \& Yamamoto, S. (2008) IgG4-related inflammatory abdominal aortic aneurysm associated with autoimmune pancreatitis. Pathol Int., 58, 421-426. doi: 10.1111/j.1440-1827.2008.02247.x.

8. Matsumoto, Y., Kasashima, S., Kawashima, A., Sasaki, H., Endo, M., Kawakami, K., et al. (2008). A case of multiple immunoglobulin G4-related periarteritis: a timorous lesion of the coronary artery and abdominal aortic aneurysm. Hum Pathol., 39, 975-980. doi: 10.1016/j.humpath.2007.10.023.

9. Qian, Q., Kashani, K. B., \& Miller, D. V. (2009). Ruptured abdominal aortic aneurysm related to IgG4 periaortitis. $N$ Engl J Med., 361, 1121-1123. doi: 10.1056/NEJMc0905265.

10. Sakata, N., Tashiro, T., \& Uesugi, N. (2008) IgG4-positive plasma cells in inflammatory myofibroblastic tumor: inflammatory abdominal aortic aneurysm: the possibility of an aortic manifestation of IgG4-related sclerosing disease. Am J Surg Pathol., 32, 553-559.

11. Stone, J. R., Khosroshahi, A., \& Deshpande, V. (2010). IgG4-related systemic disease accounts for a significant proportion of thoracic lymphoplasmacytic aortitis cases. Arthritis Care Res(Hoboken), 62, 316-322. doi: 10.1002/acr.20095.

12. Stone, J. R. (2011) Aortitis, periaortitis, and retroperitoneal fibrosis, as manifestations of IgG4-related systemic disease. CurrOpin Rheumatol., 23, 88-94. doi: 10.1097/BOR.0b013e$3283412 \mathrm{f7c}$.

13. Cheuk, W., Yuen, H. K., Chu, S. Y. Chiu, E. K, Lam, L. K., \& Chan, J. K. (2008). Lymphadenopathy of IgG4-related sclerosing disease. Am J Surg Pathol., 32, 671-681. doi: 10.1097/ PAS.0b013e318157c068.

14. Wong, D., Pillai, S., Kumarasinghe, M., McGettigan, B., Thin, L. W., Segarajasingam, D. S., et al. (2012). IgG4-related sclerosing disease of the small bowel presenting as necrotizing mesenteric arteritis and a solitary jejuna ulcer. Am J Surg Pathol., 36, 929-934. doi: 10.1097/PAS.0b013e3182495c96.

15. Chetty, R., Serra, S., \& Gauchotte, G. (2010). Sclerosing nodular lesions of the gastrointestinal tract containing large numbers of IgG4 plasma cells. Adv Anat Pathol., 17, 303-332.

\section{Відомості про авторів:}

Дядик О. О., д-р мед. наук, професор, зав. каф. патологічної та топографічної анатомії, Національна медична академія післядипломної освіти імені П. Л. Шупика, м. Київ, Україна, E-mail: alena0566@gmail.com.

Бекетова Ю. І., канд. мед. наук, асистент каф. патологічної анатомії, Національний медичний університет імені О. О. Богомольця, м. Київ, Україна.

Горбоконь Н. М., канд. мед. наук, лікар-патологоанатом, Діагностично-консультаційний центр CSD Health Care, м. Київ, Україна.

Іванова М. Д., канд. мед. наук, асистент каф. патологічної анатомії, Національний медичний університет імені О. О. Богомольця, м. Київ, Україна. 
Сведения об авторах:

Дядык Е. А., д-р мед. наук, профессор, зав. каф. патологической и топографической анатомии, Национальная медицинская академия последипломного образования имени П. Л. Шупика, г. Киев, Украина, E-mail: alena0566@gmail.com.

Бекетова Ю. И., канд. мед. наук, ассистент каф. патологической анатомии, Национальный медицинский университет имени А. А. Богомольца, г. Киев, Украина.

Горбоконь Н. Н., канд. мед. наук, врач-патологоанатом, Диагностико-консультационный центр CSD Health Care, г. Киев, Украина.

Иванова М. Д., канд. мед. наук, ассистент каф. патологической анатомии, Национальный медицинский университет имени А. А. Богомольца, г. Киев, Украина.

Information about authors:

Dyadyk O. O., MD, PhD, DSci, Professor, Head of the Department of Pathological and Topographic Anatomy, P. L. Shupyk National Medical Academy of Postgraduate Education, Kyiv, Ukraine.

Beketova Yu. I., MD, PhD, Assistant, Department of Pathological Anatomy №1, Bogomolets National Medical University, Kyiv, Ukraine.

Gorbokon N. M., MD, PhD, Pathologist, Diagnostic and Consultative Center "CSDHealthCare", Kyiv, Ukraine.

Ivanova M. D., MD, PhD, Assistant, Department of Pathological Anatomy №1, Bogomolets National Medical University, Kyiv, Ukraine. 